\title{
Development of Learning Media Based on Comic to Increase Students' Learning Outcomes at Junior High School
}

\author{
Novi Ning Diah ${ }^{1}$, Elfis $^{2}$, Prima Revelation Titisari ${ }^{3}$ \\ \{noviningdiah72@gmail.com ${ }^{1}$, email.elfis@gmail.com², pw.titisari@edu.uir.ac.id ${ }^{3}$ \} \\ 1,2,3Riau Islamic University, Riau, Indonesia
}

\begin{abstract}
The limited number of learning media used in schools causes a problem in learning activity that can affect learning outcome. Comic combines elements of education and entertainment so that can make learning activities become interesting and fun. Learning using comic is expected to make student understanding difficult material. This research is Development research by using ADDIE model. The results of the validation from the material, learning, and media experts show level of validity of the products is very valid. The results of the practicality test is efficient and the results of the effectiveness test of the use of comic showed a significant increase cognitive and psycho-motor aspect in the high category. The gain value of increasing student understanding by using science education comics is 0.81 with a high category. Thus the science education comics learning media can be used as science learning media at junior high schools.
\end{abstract}

Keywords: learning media, comic

\section{Introduction}

The learning process is a communication process that is a process of delivering information of the subject matter through particular media on the learner as the receiver of the message. As a process, academic learning requires active participation, construction, and integration on psychomotor and cognitive aspects[1]. The learning process has two very important element is the method of teaching and learning media[2]. Learning media is one of the factors that determine the success of the learning activities. The material presented in the media should be attractive, easy to understand and be able to motivate learners[3].

The use of media that have not been up in schools causing maximal learning outcomes of students. The media used in schools is a conventional learning media such as books and there are variations in the types of media that are used for learning activities. This led to low interest in learning who indicated directly on student learning outcomes.

Based on these problems researchers developed an educational comic-based learning media that cover topics IPA circulatory system. In this case the comics have flexibility as a means of education and entertainment[3]-[5]. The use of comic science education in the learning activities into interesting teaching strategies in science teaching[6]. Comics as visual media is able to give effect to the acquisition of knowledge of students as a result of learning, in the context of pedagogical comic closely related to affective aspects that can attract the 
interest and attention of students in receiving information[3], [7], [8]. Media comic uses a complex interaction between text and images so as to convey the concept and effectively motivate student involvement[9], [10].

Not maximal learning outcomes of students due to lack of instructional media use in schools to encourage researchers to develop innovative learning media can simultaneously be accessed by learners in learning activities in schools as well as independent learning so that learners' learning outcomes can be obtained maximally. Learning to use a cartoon illustration of media and literary works have been shown to improve attention and literacy skills of learners[11]-[13]. The use of comics as a medium of learning media has been widely implemented in previous research[8], [14]-[22] however for further research that examines the influence of comics on improving student learning outcomes remains to be done.

Based on the above then, researchers developed a comic science education for junior high school students on the material circulation system. The purpose of this study was to develop and determine the level of effectiveness of the comic medium to improve the learning outcomes of students.

\section{Methods}

Research conducted by the researchers is the development of research which uses research methods Research and Development with ADDIE models. The method used aims to produce a specific product and test the activity of these products. Research conducted focusing on the development of the comic-based learning media education in material science circulatory system. This study used the whole stage which is owned by the model ADDIE that consist, Analyze, Design, Development, Implementation, and Evaluation.

Implementation of development research has been conducted in four Junior High School in the city of Pekanbaru, amounting to 40 students. The data collection technique used is the validation of learning media that covers the material, learning and media. Instruments used include validation sheet filled out by the validator and the student questionnaire responses were filled by students.

Data analysis techniques applied in this study are the result of data analysis and validation of student responses. Students response data obtained from the responses that have been filled by students from Junior High School in Pekanbaru, the data obtained by dividing the total score obtained and then converted with the feasibility criteria[23].

Table 1. The eligibility criteria in the judgment of the validator

\begin{tabular}{ccl}
\hline No. & Eligibility criteria & \multicolumn{1}{c}{ Feasibility level } \\
\hline $\mathbf{1}$ & $70.01 \%-100 \%$ & Very feasible, or it can be used without revision \\
$\mathbf{2}$ & $34.01 \%-70 \%$ & Quite feasible, or can be used with minor revisions \\
$\mathbf{3}$ & $01.00 \%-34 \%$ & Less feasible, or needed major revisions \\
\hline
\end{tabular}




$$
\begin{aligned}
\mathrm{V} m a & =\frac{T S e}{T S h} \times 100 \% \\
\mathrm{Vme} & =\frac{T S e}{T S h} \times 100 \% \\
\mathrm{~V} p & =\frac{T S e}{T S h} \times 100 \% \\
\mathrm{Vs} & =\frac{T S e}{T S h} \times 100 \%
\end{aligned}
$$

Information:

VMA = Validation of the feasibility of the material

$\mathrm{VME}=$ Validation of the feasibility of the media

$\mathrm{Vp} \quad=$ Validation of the feasibility of learning

vs $\quad=$ Validation students

TSH $=$ Total score maximum expected

Tse $\quad=$ Total score empirical (the results of the feasibility test validator)

Furthermore, the study continued to examine the effectiveness of the comics media student learning outcomes. The design used in this study is the One Group Pretest Posttest Design[24].

$$
O_{1} \rightarrow X \rightarrow O_{2}
$$

Fig. 1. Chart design of the study one group pretest-posttest design.

Information:

$\mathrm{O} 1=$ Pretest to identify students' abilities

$\mathrm{O} 2=$ Posttest to identify student learning outcomes

$\mathrm{X}=$ Treatment in the form of learning using educational comic IPA

Goal of this study consisted of a sample population. The population of this research that junior high school students who have studied the material in the circulation system SMPN5 Tualang. While this sample using a small group numbering 10 students selected at random.

In the assessment of cognitive aspects of these groups were given the initial test (pretest) and then treated (teaching with media educational comic IPA). After it was given a final test (posttest). Learning outcomes of both tests were compared. Differences in the two tests shows the impact of the treatment given, then, score gain is converted into criteria[25],

$$
\frac{\%<S f>-\%<S i>}{\%<\max >-\%<S i>}
$$




$$
\begin{aligned}
& \text { Information: } \\
& \begin{array}{ll}
\mathrm{G} & =\text { Score gain } \\
\mathrm{Sr} & =\text { Score end (posttest) } \\
\mathrm{Si} & =\text { Initial scores (pretest) } \\
\mathrm{Smax} & =\text { Total empirical score }
\end{array}
\end{aligned}
$$

On the psychomotor aspects of the performance of the data obtained from discussions and presentations. Data from performance then summed to be averaged. The average score will be converted into interval assesment [26],

Table 2. interval Rate

\begin{tabular}{lll}
\hline interval & Predicate & Information \\
\hline $91-100$ & $\mathrm{~A}$ & Very good \\
$81-90$ & $\mathrm{~B}$ & Good \\
$70-80$ & $\mathrm{C}$ & Average \\
$<70$ & $\mathrm{D}$ & Below average \\
\hline
\end{tabular}

\section{Result and Discussion}

\subsection{Result}

Based on the result of validation comic media obtained on average in the material, learning and media aspect of $90 \%$ (very valid), $90.28 \%$ (very valid) and $85 \%$ (very valid). ased on the results of the comic media validation results in the aspects of material, learning, Validation comics-based learning media for science education received an average rating of $88.42 \%$ with a very valid category.

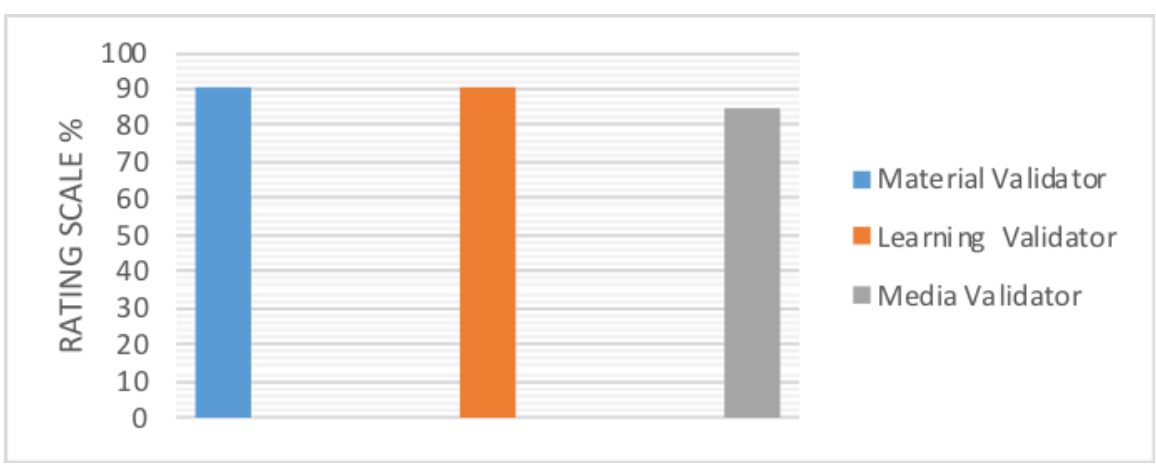

Fig. 2. The results of the comic media by the validator material, learning, and media.

Based on data from students' response to the comic media obtained data on student responses on motivational aspects, convenience, usefulness and attractiveness of $84.02 \%$ (very valid), $91.66 \%$ (very valid), $88,01 \%$ (very valid), and $86.03 \%$ (very valid). The average results of a rating of $87.43 \%$ with a very valid category. 


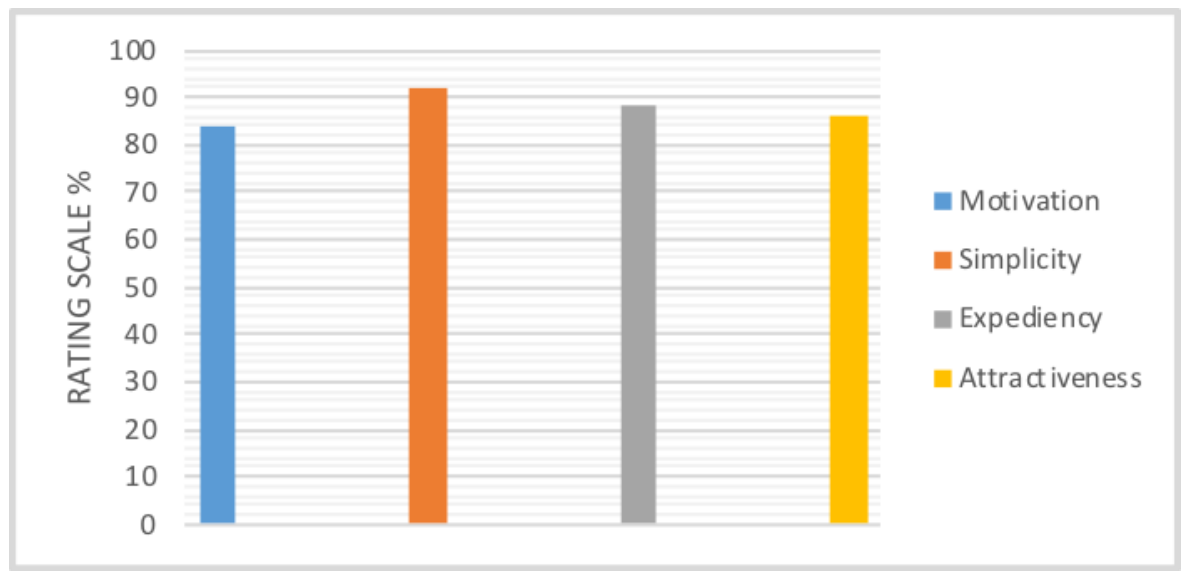

Fig. 3. The response of students to the comics media

Based on the results of the validation of comic media obtained on average in the material, learning and media aspects of 90\% (very valid), $90.28 \%$ (very valid) and $85 \%$ (very valid). The average rating result is $88.42 \%$ with a very valid category.

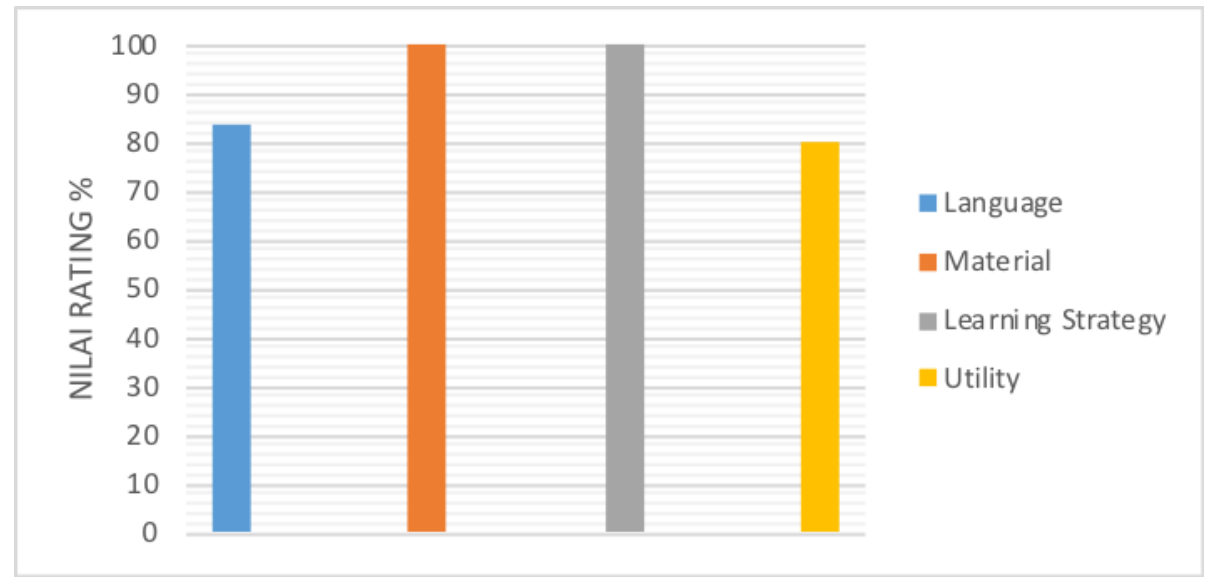

Fig. 4. The response of students to the comics medium

Practicality test conducted on comics-based learning media on science education in the aspects of language, material, learning strategies and usability is $83.33 \%$ (very practical), $100 \%$ (very practical), $100 \%$ (very practical), and $80 \%$ (very practical). From the practicality test data obtained an average of $89.58 \%$ with a very practical category. 


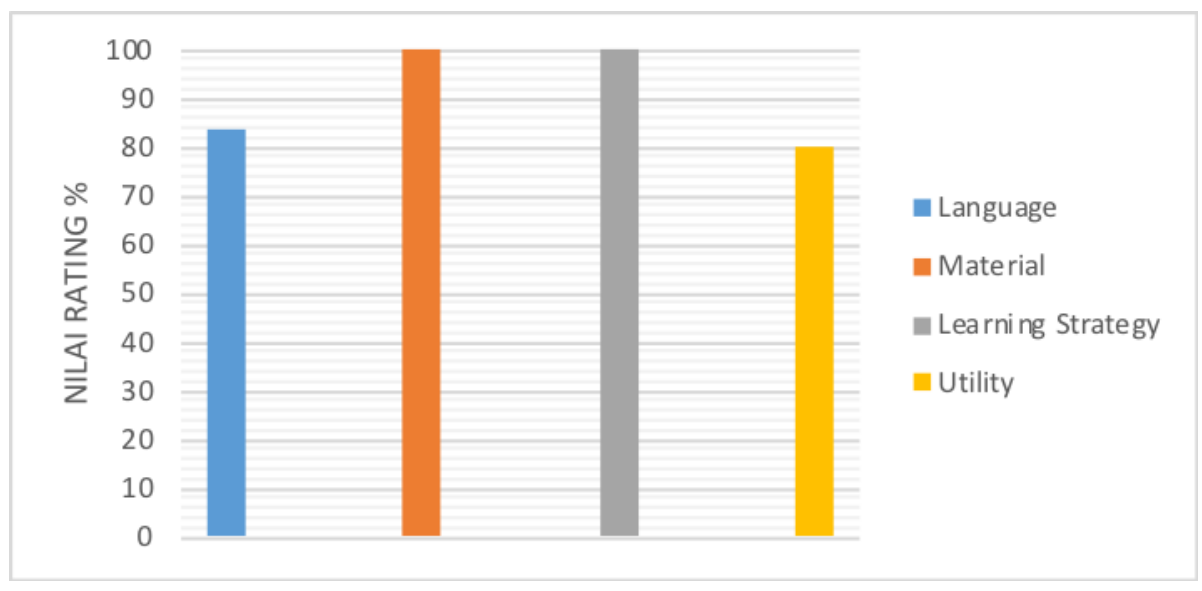

Fig. 5. The practicalities of the test results by a science teacher.

Based on the data of pretest and posttest there is a difference between the results of two tests. On the pretest results obtained results are lower than the posttest. Value gain an improved understanding of the students using educational comic IPA is 0,81 (height). On the psychomotor aspects of the average value obtained from the student presentations and discussions 85.5 with the high category.

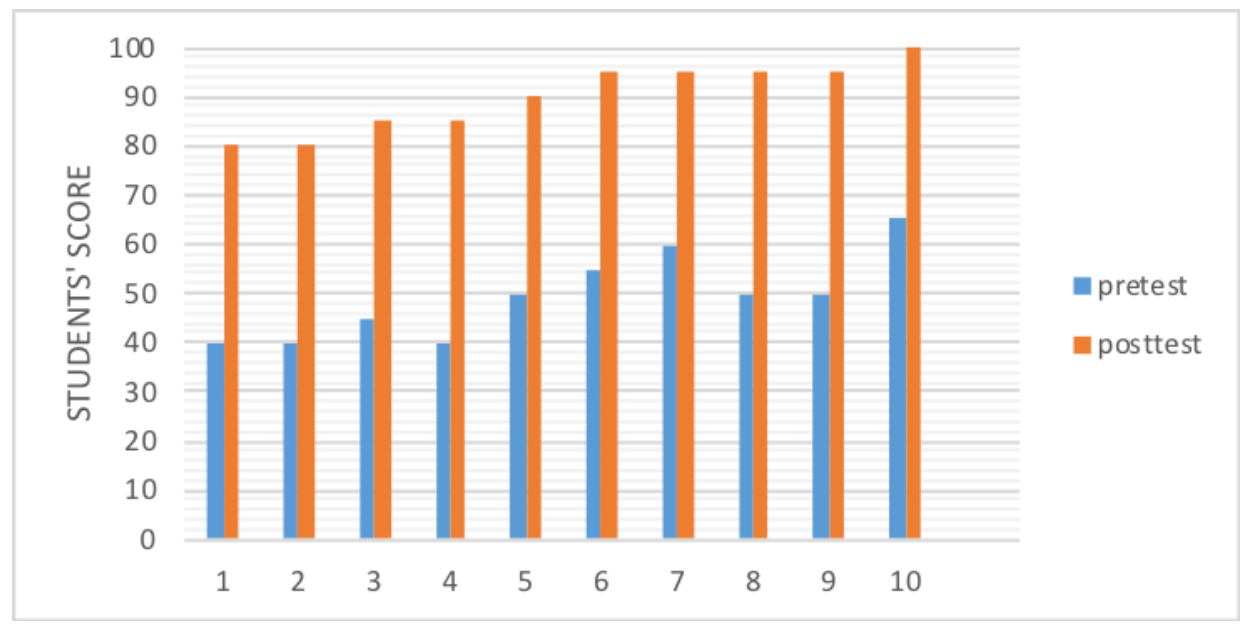

Fig. 6. Results pretest and posttest learners.

\subsection{Discussion}

Based on research that has been done can be seen that the developed instructional media declared feasible by the results of the validation of the media. The results of the validation aspects of the media are in the lowest scores when compared with the learning aspect and the material. But despite the media aspect is an aspect with the lowest score, the feasibility aspect 
of the media remains in the category of very valid based learning media assessment scale feasibility[23],

The low score is influenced by the quality of the media aspects of learning media comics on display indicator thorough presentation of the material containing the circulatory system in the form of comics. In this case there are differences in the aesthetic assessment by media validator. This was due to aesthetic valuation basis is a difficult thing to understand is understood as aesthetic appreciation on the one hand relying on the preferences of the validator media art style.

In limited trial on student responses obtained from the four aspects are considered, the lowest score is the motivational aspect and the highest score on the aspects of ease. However, although the motivational aspects of scoring the lowest compared to the other three, the feasibility aspect of motivation remains in the category of very valid based learning media assessment scale feasibility[23]. Intrinsic motivation and dealing with individuals and activities. Someone motivated to certain things, and not everyone is motivated to the same thing. Motivational orientation in attitude and purpose underlying the onset of action[27], In this study, every student has a level of motivation that is different to the comics media. Motivation is a process that supports human activity at a certain level. Good instructional media to attract the attention of students, so that students can be motivated in learning activities. Thus directly motivational aspects directly related to the attractiveness of the media aspects of comics[28].

In the aspect of convenience, the indicators assessed include the use and presentation of the material in the comic medium. The simple delivery of content on the comic medium learners make it easier to understand the material circulation system which is considered difficult. Material abstract of the circulatory system, including microscopic objects, organs and continuous process and microscopic objects. The use of cartoons illustrations and shorter text make delivery of material to be simpler and easier to understand by learners. This is consistent with the role of the comic media as a provider of visual associations that support the understanding of abstract concepts better than conventional learning media are written in standard[29]. Besides the aspect of expediency indicate that the medium of comics can provide benefits increase interest in reading through learners[30],

The benefit aspect directly relates to the motivational aspect which indicates that the four aspects of the trial are limited students' responses to the learning media affect each other. From the student response data it can be concluded that the results of the validity of the science education comics media obtained an average rating of $87.43 \%$ with a very valid category. Based on the data results of comic media validation on the material, learning aspects, it can be concluded that the results of the validity of science education based comics learning media get an average rating of $88.42 \%$ with a very valid category. This indicates that the comic-based learning media developed were declared valid as learning media. Another indication shown from the results of the validation is that the learning media developed also meet the comic criteria, which are able to interpret the text in the form of illustrations and not just tell the plot like conventional illustrations. [31],

Based on these four aspects are considered, the lowest score is the utility aspect. However, although aspects of motivation scored the lowest compared to the other three, the feasibility aspect of utility remain in the category of very valid based learning media assessment scale feasibility. Utility aspects include the use of media in comics as an educational tool in the learning activities.

In the aspect of usability is divided into four sub-indicators covering the use of media as a whole, its role as a guide in learning activities and performance as a medium of learning. 
Media comic also makes the process of delivering information to be more comfortable because the content is light, but do not leave the aspects of education[20], [32], Based on data from the trial results practicalities aspects of utility, the comics media otherwise be able to deliver information to learners and fit for use as a learning tool.

Based on the information obtained learners through comic media, will directly increase the knowledge indicated to the interpretation of learners in the form of treatment of the information it receives. This is in line with the ongoing activities of learning, namely the synthesis and integration into the information received in the form of knowledge and experience gained to determine the interactive learning[33], [34]. Referring to the one subindicators contained in the usability aspect is the role of the comic medium to guide the direction of the conventional learning into active learning. Promote active learning requires the development of partnerships for learning. In this case the active learning not only be supported through the medium of comics learning, but also must be supported by other factors such as teachers and learners[35],

The highest score on the practicality test lies in the material aspects and learning strategies. Based on these results the comic media in this study has succeeded in converting material into comics, and can be used as a pedagogical strategy. Comic media are flexible and can be combined in a variety of methods, models, and approaches that will be used by teachers, tailored to the needs and learning objectives to be achieved.

The integration of comic media is considered to help students in building a pleasant learning atmosphere. This makes it easier for students to understand the material so that confidence arises to express their opinions. Comics are a suitable medium for training students in problem solving, because many allude to problems that occur in the environment. The use of comic media in learning activities by educators has a wide range, meaning that comic media are not only used by educators in one particular level of education, but can reach audiences from various educational circles. Increased student activity in participating in learning has been stated in previous research [6], [36], [37].

Based on the pretest and posttest results data there are differences between the results of the two tests. In the pretest results obtained lower results than the posttest results. This indicates that the use of comic media can improve student learning outcomes. In the posttest results seen differences in learning outcomes in students, where learning outcomes differ from each other. Differences in student learning outcomes related to individual internal processes. Where the processing of information that they have obtained after being given a service (comic media) is bound to their own mental and bodily processes, because learning outcomes are actually the product of learners [38]. Basically every learner has a different learning capacities so as indicated on learning outcomes for learners different[39].

The study of students is the outcome resulting from the process of self reflecting resulting in a change in learning outcomes. When the self-reflection, a person makes in-depth assessment of the process of learning, motivation, beliefs, plans, and results[40]. The process is internal and vary between individuals from one another. So it can be interpreted that every student has their own way to take responsibility for their own learning process[41], [42].

Posttest results of students showed satisfactory learning outcomes, in terms of the average value higher than the completeness score score of 70. Improvement in cognitive aspects will directly affect psychomotor learning outcomes. In the psychomotor aspect the students' average score was 85.5 with a high category. Satisfying student learning outcomes directly will have an impact on long-term learning motivation [43]. This indicates that the student is able to absorb the material using instructional media educational science comic. The 
results of a similar study showed that the use of comics as a medium of learning media can improve the learning outcomes of students[17], [44] - [46],

Based on research data and explanations above, the comic book-based learning media education can be an important and effective tool for learning materials science, in addition to the use of media comic shows its contribution in shaping the attitudes of the students in a positive way and is able to entertain as well as educate learners [9], [10], [18], [47], [48],

\section{Conclusion}

The conclusion of the research that has been done is that science education based comics learning media can be used as learning media on the circulation system material. This is indicated by an increase in student learning outcomes from the cognitive aspect with N-Gain with a high category, and on the psychomotor aspects students get an average score with a high category. It is necessary to develop learning media based on science education comics on other materials. In addition to improving comic book learning outcomes, it can also increase student interest in learning. In the learning process apperception presented at the beginning of learning activities should not only focus on the material but must also be able to increase the motivation of students at the beginning of learning.

\section{References}

[1] ES Frăsineanu, "Approach to Learning Process: Superficial Deep Learning at Learning and Students," Procedia - Soc. Behav. Sci.2013.

[2] Slameto, Learning and Factors Affecting, Literacy Development, 1988.

[3] A. Cahyono, Isnandar, and B. Usodo, "Implementation of mathematical comic on exponent and logarithms with 21 st century skills - Oriented" J. Phys. Conf. Ser., Vol. 1211, no. 1, 2019.

[4] S. Te Tsai, "Design of intelligent comic makeup system for educational application based on comic script creation," Eurasia J. Math. Sci. Technol. Educ., Vol. 14, no. 3, pp. 1023$1041,2018$.

[5] S. McNicol, "humanising illness: presenting health information in educational comics," Med. Humanit., Vol. 40, no. 1, pp. 49 LP - 55, Jun. 2014.

[6] A. Wiegerová and H. Navratilova, "Let's Not Be Scared of Comics (Researching Possibilities of Using Conceptual Comics in Teaching Nature Study in Kindergarden)," Procedia - Soc. Behav. Sci., 2017.

[7] G. Mallia, "Learning from the sequence: The use of comics in instruction," ImageTexT Interdiscip. Comics Stud., Vol. 3, no. 3, pp. 1-10, 2007.

[8] M. Farinella, "The potential of comics in science communication," J. Sci. Commun., Vol. 17, no. 1, pp. 1-17, 2018.

[9] J. Hosler and KB Boomer, "Are comic books nonmajors an effectiveway to engage in learning and appreciating science ?," CBE Life Sci. Educ., Vol. 10, no. 3, pp. 309-317, 2011.

[10] A. Negrete, "Constructing a Comic to Communicate Scientific Information about the Sustainable Development and Natural Resources in Mexico" Procedia - Soc. Behav. Sci.2013. 
[11] P. Rocamora-Pérez, R. López-Liria, JM Aguilar-Parra, D. Padilla-Góngora, M. del Pilar Díaz-López, and ME-Muñoz Vargas, "The Graphic Novel as an Innovative Teaching Methodology in Higher Education: experience in the Physiotherapy Degree Program at the University of Almeria, " Procedia - Soc. Behav. Sci., 2017.

[12] FA Bieri et al."Development of an educational cartoon to Prevent worm infections in chinese schoolchildren," Infect. Dis. Poverty, vol. 2, no. 1, pp. 1-9, 2013.

[13] MG Sim, AC McEvoy, TD Wain, and EL Khong, "Improving health Professional's knowledge of hepatitis B using cartoon-based learning tools: A retrospective analysis of pre- and post-tests," BMC Med. Educ., Vol. 14, no. 1, pp. 1-8, 2014.

[14] N. Nurlatipah, "Media Development Science Learning Comics That Accompanied Photos To Improve Student Results Class Vii SMPN 2 Source By Topic Ecosystems," Sci. Educ., Vol. 4, no. 2, 2015.

[15] VN Yulian, "Developing Teaching Materials Using Comic Media to Enhance Students' Mathematical Communication" IOP Conf. Ser. Mater. Sci. Eng., Vol. 335, no. 1, 2018.

[16] S. Fatimus, Utariyanti Zahro ISMI; Wahyuni, Sri; Zaenab, "Comic-Based Learning Media Development In the Matter Respiratory System On Mts viii grade students Muhammadiyah 1 Malang,"JPBI (Journal of Educators. Biol. Indones., Vol. 1, no. 3, pp. 343-355, 2015.

[17] I. Damopolii and SR Rahman, "The effect of STAD learning model of comics and science students on cognitive achievement," J. Phys. Conf. Ser., Vol. 1157, no. 2, 2019.

[18] B. Jee and FK Anggoro, "Cognitive Impacts of Science Comics," J. Cogn. Educ. Psychol., Vol. 11, no. 2, 2012.

[19] A. Farthing, "illustrating Cognition - A Review of The Visual Language of Comics," Comics comics Scholarsh J. Grid., Vol. 4, no. 1, pp. 1-3, 2014.

[20] A. Joshi et al."Comics as an Educational Tool on a Clinical clerkships," Acad. Psychiatry, vol. 43, no. 3, pp. 290-293, 2019.

[21] P. Hendarto and BA Prayitno, "Effectiveness of Guided Inquiry-Based Modules include comics to Argue ability in terms of Students Reading Interest," no. 1, pp. 1652-1663, 2018.

[22] "THE USE OF webtoon AND KWL (KNOW-WANT-LEARN) STRATEGY TO IMPROVE STUDENTS 'READING Fluency (A Classroom Action Research in the tenth grade of SMK MuhammadiyahRembang in the Academic."

[23] S. Akbar, "Instruments learning device." Bandung: PT Young Rosdakarya, 2013.

[24] N. Sukmadinata; Syaodih,Educational Research Methods, Bandung: PT. Youth Rosdakarya, 2013.

[25] DE Meltzer, "The relationship between mathematics preparation and conceptual learning gains in physics: A possible 'hidden variables' in diagnostic pretest scores," Am. J. Phys., Vol. 70, no. 12, pp. 1259-1268, 2002.

[26] D. by the Ministry of Education and Culture Directorate General of Primary and Secondary Education Directorate of Junior Secondary Education, "Free Rate by Educators and Junior High School Education Unit Mold Fourth, the State Property 2017 is not traded Writer Tim Directorate of SMPS designs Lubis MS Visual Source illustrations, "2017.

[27] RM Ryan and Deci EL, "Intrinsic and extrinsic Motivations: Classic Definitions and New Directions," Contemp. Educ. Psychol.2000.

[28] O. Zaikin, M. Malinowska, Bakhtadze N., and A. Zyławski, "Motivation and social aspects of competence-based learning process," in Procedia Computer Science, 2017.

[29] F. Affeldt, D. Meinhart, and I. Eilks, "The Use of Comics in Experimental Instructions in 
a Non-Formal Learning Chemistry Context," Int. J. Educ. Math. Sci. Technol., Pp. 93$104,2018$.

[30] L. Tiemensma, "Visual literacy: to comics or not to comics? Promoting literacy using comics, "World LiBr. Inf. Congr. 75th IFLA Gen. Conf. Assem., Pp. 1-10, 2009.

[31] SH Kuo, "The Art of Making Animals Laugh Benjamin Rabier's Comic-Illustration of Les Fables de La Fontaine" Neophilologus, Vol. 97, no. 1, pp. 21-33, 2012.

[32] A. Mendelson et al."Comics as an educational tool for children with juvenile idiopathic arthritis," Pediatr. Rheumatol., Vol. 15, no. 1, p. 69, September 2017.

[33] N. Cue, "A universal learning tool for classrooms," Proc. First Qual. Teach. Learn. Conf., No. December, pp. 10-12, 1998.

[34] KS Khan and A. Coomarasamy, "A hierarchy of effective teaching and learning to acquire competence in evidenced-based medicine," BMC Med. Educ., Vol. 6, pp. 1-9, 2006.

[35] L. Marioara, "The Change for Education in Need Student-centered learning," Procedia Soc. Behav. Sci., 2015.

[36] K. Comer, "illustrating Praxis: Comic Composition, Narrative Rhetoric, and Critical multiliteracies," 2015.

[37] A. Barbosa DA Silva, G. Tavares Dos Santos, A. DE Carolina Kruta Araújo Bispo, A. Barbosa da Silva, and G. Tavares dos Santos Ana Carolina Kruta de Araújo Bispo, "THE COMICS AS STRATEGY IN LEARNING TEACHING OF AN UNDERGRADUATE STUDENTS IN MANAGEMENT PROGRAM," Manag. Rev., vol. 18, no. 1, pp. 40-65.

[38] H. Pätzold, "Reflections on Learning," in Learning and Teaching in Adult Education, 1st ed., Barbara Budrich Verlag, 2011, pp. 79-90.

[39] CBP Singh, "Classroom Ecology and Students 'Learning Style: A Study in an Elite Professional College Classroom Ecology and Students' Learning Style: A Study in an Elite Professional College Introduction," vol. 1, no. 1, pp. 1-12, 2019.

[40] MH van Loon, "Self-Assessment and Self-Reflection to Measure and Improve SelfRegulated Learning in the Workplace," in Handbook of Vocational Education and Training: Developments in the Changing World of Work, S. McGrath, M. Mulder, J. Papier, and R. Suart, Eds. Cham: Springer International Publishing, 2019, pp. 1-20.

[41] A. Curaj, L. Matei, R. Pricopie, J. Salmi, P. Scott, and (Eds), The European Higher Education Area, 2015.

[42] A. Mikroyannidis, Responsive Open Learning Environments, 2015.

[43] Y.-C. Wu, L.-F. Hsieh, and J.-J. Lu, "What's The Relationship between Learning Satisfaction and Continuing Learning Intention ?,"Procedia - Soc. Behav. Sci.,, 2015.

[44] W. Mutia and EE Subekti, "Usage Model Sharing," J. penelit. Educators., Vol. 34, no. 5, pp. 173-182, 2017.

[45] Y. daughter, Gloria RY, and A. Mulyani, "The Effectiveness of Using Learning Bioentrepreneurship Comics on the Sub Concepts of Angiosperms for High School Students," Sci. Educ., Vol. 7, no. 2, p. 159, 2019.

[46] A. Widyawati and A. Wijayanti, "The Effect of Media Comic Character Based Science Of Interest Read And Education Student Learning Outcomes Ipa," vol. 5, no. 1, pp. 6677, 2019.

[47] C. Matuk, T. Hurwich, A. Spiegel, and J. Diamond, "How Do Teachers Use Comics to Promote Engagement, Equity, and Diversity in Science Classrooms?," Res. Sci. Educ., 2019.

[48] AN Spiegel, J. McQuillan, P. Halpin, Matuk C., and J. Diamond, "Engaging Teenagers with Science Through Comics," Res. Sci. Educ., Vol. 43, no. 6, pp. 2309-2326, 2013. 